\title{
The Use and Administration of Audio- $V$ isual Materials in Colleges in the Pacific Northwest:
Report of a Survey
}

Miss Brainard is head of circulation, John McIntire Public Library, Zanesville, Ohio, and formerly assistant librarian, Portland State Extension Center, Portland, Oregon.

$\mathrm{T}$ HIS SURVEY was undertaken to learn what four-year colleges in the Pacific Northwest are doing and have been doing in the use and administration of audio-visual materials. The colleges to which the questionnaire was sent are located in Oregon, Washington, Montana and Idaho, and are those listed in Lovejoy's Complete Guide to American Colleges and Universities. State universities were not included nor was Oregon State College. This was done because obviously the universities' funds and facilities would be much larger than those of the other educational institutions in this region. Oregon State was not included because on its campus is the Division of Visual Instruction which serves all the schools in the Oregon State System of Higher Education.

The colleges returning the questionnaire present a cross section of institutions of higher education in the Northwest. These comprise I2 small, private, liberal arts colleges, four colleges having a combined program of liberal arts and teacher training, two teachers colleges, two land-grant schools, and one technical institute. Enrolments range from I IO to 5000 students and faculties from ro to 600 ; eight schools have more than 1000 students, six have 500 or more and six have less than 500.

The questionnaire was designed to gather information regarding audio-visual aids used, the subject fields in which used, selection of materials, the handling of those of which the library has charge, the records kept to facili- tate ordering, scheduling, lending of films and other materials, and suggestions for improvement of their present programs.

Of the audio-visual aids used in the colleges replying, films, filmstrips, slides and recordings are the most popular; transcriptions and flat pictures are less in demand. One school reported using a flannelgraph, and two, one in Idaho and one in Washington, have television sets.

The fields in which audio-visual aids are used in teaching show a wide range, implying that resources are available in many fields. Among those listed are the following: education and psychology, music, speech, foreign languages, literatures, humanities, history, business, sociology, religious education, nursing and health, physical education and training, fine arts, manual arts; and in vocational courses such as electrical, civil and mechanical engineering; metallurgy, optometry, veterinary medicine, animal husbandry, Air Force R.O.T.C.; and in the sciences-biology, chemistry, geology and physics. The order in which the above are listed here does not indicate the frequency reported in the replies.

Because previewing films and other such materials before showing has been stressed in audio-visual courses, it was somewhat surprising to find that doing so was not a general practice. Lack of time or lateness in arrival of films may be responsible for this situation.

Teaching with audio-visual aids has been going on in these colleges for some time, for a third of those replying have been using them for more than ten years, another third has been using them for ten years and the others have used them for the past five years. . All report that there has been an increase in use the past two years. The reasons which are 
given for this may be listed under headings such as (I) improved services, which include a better system of ordering and scheduling of films and improved techniques for keeping faculty informed of materials available; (2) more materials available in a larger number of fields, they can be obtained from nearby sources, quality is improved, the cost is less, and colleges have made more filmstrips and enlarged their slide collections; (3) physical equipment and facilities-new buildings have audio-visual facilities, equipment is better and there is more of it; (4) administration and faculty are more sympathetic toward the use of audio-visual teaching aids, they are more aware of the wide range available and of their value in instruction; too, more faculty members are prepared to use them; (5) more publicity given these materials, for coordinators and directors of audio-visual centers and librarians have carried on a continuous campaign to increase their use. The above reasons coupled with new courses being offered in colleges, and the development of departments for acquiring equipment and collections of suitable materials have resulted in increased financial support and wider use.

There seems little relationship in the size of the college and the amount of equipment owned by it. Rather the type of school and subject fields emphasized in the curriculum seem to determine the situation. The one technical institute replying has an enrolment of 258 students and owns 28 projectors; a state college with an enrolment of 5000 students owns 20; and a school with a combined liberal arts-teacher training program and I074 students has I3, the next largest number. Both students and faculty members operate the equipment, but faculty members or members of the audio-visual department take care of it. In several colleges students care for it under the supervision of faculty. In addition to projectors the schools own different types of slide projectors, recorders, both wire and tape, filmstrip previewers, radios, playback machines and television sets.

Audio-visual materials for purchase are selected by various persons, no one person or department being responsible in all the schools. In some the librarian and the business manager do the selecting. In others faculty members recommend and the business manager decides which ones will be purchased. Or the heads of departments choose the ones after conferences with their members. In schools having coordinators or directors of audiovisual programs, these do much of the selecting in conference with faculty. When films are rented, faculty members select them.

According to replies received, there are few or no standard sources used in the selection of these teaching aids. Two small, liberal arts colleges go to local audio-visual companies in Portland where the schools are located. Another small, private college with close denominational affiliation, consults its field men. Another bases its selection on materials with which the faculty is familiar. One college gave this list as the source its faculty consults: "catalogs available such as Coronet, Jim Handy, Northern School Supply, Free Films, Slide Films, and Teaching Film Annual." The State College of Washington at Pullman has an extensive program of selection about which it says: "We have a complete file of all sources. A staff of seven has spent the past year in searching for and screening 6500 films and filmstrips to approve those suitable for use as overseas training and information films. These are now being used by the U.S.A. in the Marshall Plan countries." Not any of the other colleges reporting have such extensive resources or facilities. When selecting materials some refer to lists in textbooks, in professional journals, and to lists from public libraries, industries and large corporations.

Small colleges are just beginning to set up programs for purchase of equipment and materials. The larger ones, on the other hand, have extensive plans for expansion of their programs. Budgets range from $\$$ Ioo in the smaller institutions to $\$ 8000$ in the largest. One college has $\$ 2000$ for purchase of equipment and an equal amount for materials. Some have no separate budget for this kind of material and part of the library fund is used.

The schools having programs and budgets also have storage facilities for their equipment in audio-visual centers. In others equipment and materials are scattered over the campus in faculty members' offices, in departmental offices, and in the library. Faculty members have charge of storage places, except when the library is used in which situation a member of the library staff has charge.

Not all colleges reporting subscribe to magazines which deal with audio-visual materials. 
The two magazines most frequently received are Audio-Visual Guide and Educational Screen which go to eleven schools. See and Hear is received by four, and Audio-Visual World is listed on three replies. Other periodicals mentioned are Radio Electronics, Radio and Television News, Photography, American Photography, Sound Tips, Audio Record, and Film Counselor.

Some of the schools queried catalog their audio-visual materials, but the cards for these are kept in a file separate from the regular card catalog. Most of them rent the films they use, but slides are kept in the departments in which made, or by students if they made them. As more funds are allotted, a larger. number of schools are buying equipment and will purchase materials later.

Answers to the question of whether the library should have a part in the audio-visual program varied according to whether a library staff member or a faculty member filled out the questionnaire. Librarians, of course, replied that not only should the library have a part in the program but should be the center for audio-visual aids. Only the larger library buildings or those built or remodeled recently have adequate space. Too, only libraries having adequate staff could accept the additional responsibility of administering the program. Some of the reasons advanced by the librarians for being the audio-visual center were: the library has an established ordering system, full-time supervision is available, the library is open more hours than any office or department on the campus, and the library is not affected by sudden change of policy. This last reason might not be valid, for library practices usually conform to the needs of its students and faculty. However, the turnover in library personnel may be smaller than that in other departments. One faculty member's reply reflects the viewpoint of some, for he states: "No, it (the library) should not have (a part in the audio-visual program). Librarians have all they can do to care for books and periodicals. It is better to have a separate audio-visual center even if it is no bigger than an office for a starter. A librarian can not well take time to check machine conditions and adjust." Another faculty member wrote: "I am not a librarian, and I am wondering why librarians should want to trouble themselves with the work and the service involved. This alone can reach such a large proportion that an audio-visual coordinator who can make adjustments and minor repairs is a desirable officer. Materials are to be used and not to be waiting repair or adjustment."

The section of the questionnaire inquiring about records kept and forms used was the one most frequently not filled out. The records mentioned were requisitions for purchase, forms for requesting rental and those for loaning materials to faculty and students. Information included on these was brief, the main points being date, source from which ordered, date for which needed, title, department, cost, date when film must be returned, shipping charges. Forms for loan to faculty or students indicated date on which loaned, name of person or department to which loaned, and date returned. Order forms for purchase of material indicated date of order, source from which ordered, title or name of material wished, department or person for which ordered, date received and cost.

The suggestions for improvement of existing programs fall into general categories, such as centralization of materials and equipment in one designated storage place, separate and larger budget, increased space for quarters and staff, larger library staff to catalog materials, a full-time person to handle the materials and care for the equipment, and keeping faculty and administration informed regarding materials available.

The information provided by this survey might be summarized in this way: (I) it appears that colleges in this region are using various kinds of audio-visual aids increasingly in their instructional programs; (2) that the use of these materials is growing due to more and better equipment, the availability of more and better materials, and because more people know how to operate the equipment; (3) that college faculties are beginning to consider these aids as an essential part of their instructional materials, plan to set up programs for purchase of equipment and materials soon if they have not yet done so, and to employ a full-time trained person when the size of the program makes that necessary; (4) that faculty and administration are coming to realize that these materials can do a particular type of instruction more successfully than can be accomplished by any other means. 